\title{
Nurses' experiences in the care of high-risk newborns: a phenomenological study
}

\author{
Vivências do enfermeiro no cuidado ao recém-nascido de alto risco: estudo fenomenológico
}

Experiencias del enfermero en el cuidado del recién nacido de alto riesgo: un estudio fenomenológico

\author{
Sueli Maria Refrande' \\ ORCID: 0000-0002-1862-3455
}

Rose Mary Costa Rosa Andrade Silva'

ORCID: 0000-0002-6403-2349

Eliane Ramos Pereira'

ORCID: 0000-0002-6381-3979

Renata Carla Nencetti Pereira Rocha ORCID: 0000-0003-1053-6231

Sérgio Henrique da Silva Melo' ORCID: 0000-0002-8088-5982

Neusa Aparecida Refrande ORCID: 0000-0002-0578-7901

Ricardo Raimundo dos Santos' ORCID: 0000-0002-3516-609X

Universidade Federal Fluminense. Niterói, Rio de Janeiro, Brazil.

How to cite this article: Refrande SM, Silva RMCRA, Pereira ER, Rocha RCNP, Melo SHS, Refrande NA, et al. Nurses' experiences in the care of high-risk newborns: a phenomenological study. Rev Bras Enferm. 2019;72(Suppl 3):111-7. doi: http://dx.doi.org/10.1590/0034-7167-2018-0221

\section{Corresponding Author:}

Sueli Maria Refrande E-mail: susurefrande@gmail.com

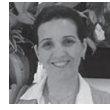

Submission: 04-06-2018 Approval: 03-09-2019

\begin{abstract}
Objective: To describe nurses' experience in the care of high-risk newborns. Method: This is a descriptive study with a qualitative approach, based on Merleau-Ponty's phenomenology and performed at the Fernando Magalhães Maternity Hospital in the state of Rio de Janeiro, through interviews with 30 nurses who work in neonatal care, according to the phenomenological thinking of Maurice Merleau- Ponty. Results: Three categories emerged: "experienced body of the nurse practitioner on the high-risk newborn"; "experienced world of the nurse practitioner on the high-risk newborn"; and "time spent by the nurse practitioner with the high-risk newborn". Final considerations: The study allowed us to describe, through the participants' speeches, that the care of the high-risk newborn is broad, that is, objective, subjective and carried out with advanced technologies, their experiences and scientific improvement are composed of shared practice and theory with the family, professionals and beginners in the neonatal universe, favoring a differentiated and humanized care.

Descriptors: Neonatal Nursing; Child Care; Newborn; Risk; Neonatology.
\end{abstract}

\section{RESUMO}

Objetivo: Descrever a vivência do enfermeiro no cuidado ao recém-nascido de alto risco. Método: Estudo descritivo com abordagem qualitativa, pautado na fenomenologia de Merleau-Ponty e realizado no Hospital Maternidade Fernando Magalhães do estado do Rio de Janeiro, por meio de entrevistas com 30 enfermeiros que atuam no cuidado neonatal, segundo o pensamento fenomenológico de Maurice Merleau-Ponty. Resultados: Emergiram três categorias: "corpo vivido do profissional enfermeiro sobre o recém-nascido de alto risco"; "mundo vivido do profissional enfermeiro sobre o recém-nascido de alto risco"; e "tempo vivido do profissional enfermeiro sobre o recém-nascido de alto risco". Considerações finais: O estudo nos permitiu descrever, através das falas dos participantes, que o cuidado ao recém-nascido de alto risco é amplo, ou seja, objetivo, subjetivo e realizado com tecnologias avançadas, suas vivências e aprimoramento científico composto do teórico prático compartilhado com a família, profissionais e iniciantes no universo neonatal favorecendo um cuidado diferenciado e humanizado.

Descritores: Enfermagem Neonatal; Cuidado da Criança; Recém-Nascido; Risco; Neonatologia.

\section{RESUMEN}

Objetivo: Describir las experiencias del enfermero en el cuidado del recién nacido de alto riesgo. Método: Estudio descriptivo de tipo cualitativo, con base en la fenomenología de Merleau-Ponty, siendo realizado en el Hospital Maternidad Fernando Magalhães del estado de Río de Janeiro, en el que se entrevistaron 30 enfermeros que actúan en el cuidado neonatal. Resultados: Se encontraron tres categorías: "el cuerpo vivido del profesional enfermero sobre el recién nacido de alto riesgo"; "el mundo vivido del profesional enfermero sobre el recién nacido de alto riesgo"; y "el tiempo vivido del profesional enfermero sobre el recién nacido de alto riesgo". Consideraciones finales: A partir de los relatos de los participantes, este estudio nos permitió describir que es amplio el cuidado del recién nacido de alto riesgo, es decir, objetivo, subjetivo y realizado con tecnologías avanzadas, que presenta vivencias y perfeccionamiento científico según la teoría y la práctica compartidas con la familia, los profesionales y los iniciantes en el universo neonatal, lo que promueve un cuidado diferenciado y humanizado.

Descriptores: Enfermería Neonatal; Cuidado del Niño; Recién Nacido; Riesgo; Neonatología. 


\section{INTRODUCTION}

The practice of neonatal nursing consists of at least three components: implementing nursing care, intervening with care, and interacting with other health professionals. It is worth remembering that the interrelation of these three components focuses on the improvement or maintenance of neonatal and family health ${ }^{(1)}$.

Corroborating with the line of thought in relation to care, the author Margaret Jean Watson developed the Human Care Theory, which considers care that transcends time, space and matter of patient and professional, so that they form a single element in tune, beyond the moment of interaction, in a way that favors the restoration. Often in the physical dimension, with the execution of technical procedures at a more advanced level of care, nursing is able to access emotional and subjective aspects, in order to objectify transpersonality through communication and empathy, which can be developed and maintain the harmony and confidence necessary for this process ${ }^{(2)}$.

Faced with a more specialized care, the technological advances in the neonatal intensive care unit (NICU) contribute to a significant change in neonatal care, giving a guarantee of survival to the newborn. The neonatal environment is also a problem for the professional nurse, generating discomfort, physical and emotional exhaustion due to the nature of the work and characteristics of the sector. Although most nursing professionals take pleasure in caring for such fragile beings, they experience moments of anguish related to complex and painful procedures in such a delicate moment of this being that is between life and death ${ }^{(3)}$.

Thus, in an environment of care with an entire technological apparatus such as the NICU, they can be associated with the benefits of the light technology, identified as work in action, the reception, the humanization attitudes and the interactions of the family of the newborn with the multidisciplinary health team. Given that, as the neonatal environment is considered complex, the nursing professional has activities that involve psychosocial risks due to prolonged working hours, tasks that require an accelerated pace, repetitive actions, insufficient personnel and material, various shifts, among others ${ }^{(3)}$.

In this sense, just as psychosocial risks are highlighted in activities developed by nursing professionals, a study emphasizes risk factors related to infants with very low birth weight, such as the occurrence of infection due to intrinsic risk factors related to immaturity of immunological development and ineffective skin barriers of protection and mucous membranes ${ }^{(4)}$. However, there is also concern about the psychosocial risks of the health team in neonatology, since it is an environment that involves many feelings, both from professionals and relatives.

The extrinsic risk factors should also be highlighted, such as the manipulation of very low birth weight preterm infants by health professionals, the hospital environment, antibiotics, parenteal nutrition and invasive devices; however, there is a need for more rigor in the techniques used in procedures with the premature infant, the quantitative of personnel and greater attention in the performance of aseptic techniques ${ }^{(4)}$.

One of the important aseptic techniques performed with the premature newborn is on the skin, as it is the largest vital organ, which protects our entire body with a whole integumentary system, contributes to thermoregulation, tactile sensation, fat isolation and storage, provides barriers against infections, toxins, losses of electrolyte fluids, and thus promotes the involvement of nurses and family members in skin-to-skin contact with the newborn ${ }^{(5)}$.

Most of the professionals in neonatology work on exclusive dedication, with only a small part of specialists who highlight the interest in participating in procedures such as the installation of the peripherally inserted central catheter, getting involved in discussions with the multiprofessional team and, mostly, in nursing care in Brazi|(6).

Nurses find themselves in functions that were formerly performed by technicians and auxiliaries, leaving the role of supervision and management to perform the tasks in patient care. From 2011, nursing care for newborns in the neonatology sector, previously performed by technicians, has been carried out by graduated professionals ${ }^{(6)}$.

Therefore, while we have a body through which we act in the world, space and time are not a sum of overlapping points, nor an infinity of relationships from which our consciousness would extract the synthesis that would imply our body. We are not in space and time, we do not think space and time; we are space and time, our body applies to them and involves them ${ }^{(7)}$.

In addition, the body of the newborn demonstrates important meanings to the nurse, who then worries about not making any mistakes, in an attitude of commitment and responsibility with the profession. And in spite of taking care of the body, they also perceive something "beyond" the body. The body that the nurse perceives but does not see is the body of experiences, of objectivity. It is the virtual or phenomenal body, the one that founds the objective body.

\section{OBJECTIVE}

To describe nurses' experience in the care of high-risk newborns.

\section{METHOD}

\section{Ethical aspects}

The study was previously submitted to the Research Ethics Committee of the Center of Medical Sciences of the Hospital Universitário Antônio Pedro, Universidade Federal Fluminense, and subsequently it was also approved by the Research Ethics and Committee of the Municipal Health Secretariat of Rio de Janeiro/ SMS/RJ, as a co-participant institution. Because it was a research involving human beings, ethical aspects were respected in accordance with Resolution 466/2012 of the National Health Council.

\section{Theory and methodology references}

The phenomenological method was used, since, according to $\mathrm{Cappi}^{(8)}$, phenomenology "is a rigorous methodological look at the real, it is a radical option of perception" in order to reveal meanings, to create values and take responsibility. Everything that is offered to human knowledge can be called phenomenal reality ${ }^{(9)}$.

The predilection for phenomenology or phenomenological method is anchored in the perspective of lived and experienced human phenomena. Its central question is the reflection on the experienced world. 
Maurice Merleau-Ponty's phenomenology of perception is based on grasping the phenomenon in its entirety through relevant aspects, such as: past and present experiences and the future in relation to the high-risk newborn in all its dimensions: perceptions, historicity, world of life, corporeality, spatiality and temporality.

Thus, the body that the man does not see and does not perceive, that is, the body of his experiences, the phenomenal, that founds the objective body and applies to space and time and involves them. They also have their world and understand it without objective functions.

\section{Type of study}

This is a descriptive study whose method is to describe the totality of the lived experience, including the sense that these experiences have for the individuals who belong to them. The research has a qualitative approach that corresponds to the one that "works with the subjectivity of the subjects" and has a descriptive character for "describing the characteristics of a given population or phenomenon ${ }^{\prime \prime(10)}$.

\section{Methodological procedures}

34 nurses participated of the study, being them head nurses, duty nurses and day laborer nurses. For data collection, day and nighttime duty and day laborer nurses and the head nurse were included, since they worked in direct care with the newborn. Licensed nurses, on vacation in the period of data collection, those had been working for less than one year and those who for some reason did not want or could not participate and sign the Informed Consent Form (ICF) were excluded, in a total of 30 nurses.

Initially, the approach and setting in the research scenario were performed with a differentiated look as a researcher. With this, it was necessary to follow day and night shifts to meet and be met by my colleagues as a researcher. The participants were interviewed at the meeting place and were previously scheduled according to the participants' availability, allowing greater freedom and minimal interference in the meetings, which are essential factors in the phenomenological research.

\section{Study scenario}

The research was based on the Fernando Magalhães Maternity Hospital (HMFM), located in Rio de Janeiro/RJ, Brazil.

\section{Data gathering and organization}

Data were collected after approval by the Research Ethics Committee and the researcher's ambiance in the research scenario, and this stage was carried out in the second half of 2015. The interviews were recorded in a magnetic device and, together, have a duration of 250 minutes of speeches by the 30 participants, from October 31, 2015 to November 30, 2015. These interviews, which were subsequently transcribed, also followed a script totaling seven questions, thus highlighting a question: "What is your perception of high-risk newborn care?". The identity of the participants was preserved and fictitious names were used, consisting of the letter N (N1, N2, N3, N4...) for the word nurse, followed by a number that did not necessarily match the sequence of participation in the research, and meeting the ethical and legal specifications of Resolution 466/2012.

\section{Data analysis}

To analyze the interviews, methodological procedures defined by phenomenology were used. It is possible to say with certainty that the philosopher Maurice Merleau-Ponty is a most important thinker for educators who intend to interpret the child and their relations with the world, with themselves and with the other; the philosopher was the only phenomenologist who left a contribution focused on the child and early childhood.

Thus, the phenomenological method must seek to access the essence of the studied fact, which can be reached from three fundamental elements. The first is phenomenological reduction, which allows to access the truth of the subject. The second is intersubjectivity, which is the relationship established between the researcher-subject and the researched-subject- - two stories that meet to understand a phenomenon. The third element is a return to the experienced, in which the researched-subject resumes their history ${ }^{(9)}$.

Initially, the speeches were read completely and attentively in order to grasp the global meaning, but without interpreting or identifying the attributes contained in them. Soon after, the identification and grouping of the descriptions of each speech were made, evident presence of the essentialities of the phenomenon.

After obtaining the units of meaning, the interview fragments that made sense and answered the guiding question were identified, highlighted, examined and submitted to thematic analysis under the Merleaupontian theoretical framework.

\section{RESULTS}

Descriptive data analysis was aimed at describing the profiles of the professionals. The sample was composed of 30 professionals, 2 male (6.7\%) and 28 female (93.3\%). Of the 30 professionals, 24 (80\%) had a refresher course in neonatology, and 6 of them (20\%) had not. The nurses took the following refresher courses: a) post-training in acupuncture and physiotherapy; b) residential training in surgical medical clinic and family health; and c) clinical and general surgery residency.

Typically, the professional participating in this research was 41 to 47 years old ( $36.7 \%$ of the cases) had graduated 8 to 13 years ago (30\%) with 1 to 6 years of experience in neonatal ICUs and worked on day duty $(50 \%)$.

When the interview data were analyzed, it was possible to describe the meanings attributed by the participants in the context of NICU experiences with high-risk newborns, allowing the apprehension of three categories, which will be shown as follows: "experienced body of the nurse practitioner on the high-risk newborn"; "experienced world of the nurse practitioner on the high-risk newborn"; and "time spent by the nurse practitioner with the high-risk newborn".

\section{Category 1 - Experienced body of the nurse practitioner on the high-risk newborn}

The first category unveiled from the nurses' statements describing the care to the newborn as an experienced body, that is, the objective body (physiological) and the subjective body (virtual). 
The objective body is only a moment in the constitution of the object. Taken from the objective world, it will draw the intentional threads that bind it to its environment and finally reveal to us the perceiving subject as well as the perceived world ${ }^{(7)}$.

Therefore, when nurses perform their activities, that is, procedures and care for the newborn, they do not try to look for their hands, their fingers, muscles, nerves, because they are not objects of this objective space, they are influences already mobilized by their perception with intentional threads that are attached to given objects. When caring for the body, the nurse perceives something "beyond" the body, that is, it is ontological. Even with the complexity of care directed to the newborn, the attitude of intersubjectivity prevails.

[...] They're an individual being [...] what one feels is what the other feels, they're different perceptions, different worlds, different little bodies, they're different feelings, they're phases of different hospitalizations, different gestational ages [...]. (N05)

[...] if they [newborns] are feeling pain, what are the characteristics of their pain, their faces, if they are crying, if you think they are crying for pain, for hunger, I think each one has its individual part. (N05)

The experience of the nurse practitioner is essential to understand the characteristics of the newborn, especially in the moment that precedes the procedures, excessive or unnecessary manipulation. The newborn shows what they are feeling through signs such as frowning, pain, hunger, fever, crying, etc. And only a professional with experience in this complex environment will notice it.

[...] first the fact of being a newborn, then, it's a child and you need to have a perception of the skills, it can't communicate with you, so there are signs that you're going to have to notice, you'll need to have not only the technical scientific knowledge but also an intuition in the care, right, depending on your time of practice, to be able to interpret the signs that the child will bring to you, right [...]. (N26)

The participant above, based on historicity, perceives the complexity of care, of their experiences in the neonatal complex, because they carry a past before being in present, the past of their experiences. With this, they understand the critical look related to the care to the newborn, describing an adequate assistance along with the multiprofessional team, even in situations of physical exhaustion.

It goes much further than a technical thing, a care, than a procedure, for example. It's a complex care to begin with, and it goes way beyond technical care, right? [...]. (N15)

With light technology, emphasizing the reception and humanized care, the neonatologist nurse seeks to build a strategy to deal with the hard technology in the NICU, which is used as work instruments, that can minimize the wearing of the premature newborn and minimally reproduce the maternal environment to finalize the growth and maturation phase of internal organs and systems.

\section{Category 2 - Experienced world of the nurse practitioner on the high-risk newborn}

In the second category, the lived experience of the nurse practitioner about the high-risk newborn was revealed. The world experience provided a vision in relation to the things that are in the world and that surround it.

[...] I had knowledge on adult intensive care and I initially sought to be able to get in here, I had to adapt that knowledge, from adult patient acute care to child conception, so everything was adapted at the time, so I tried to read a lot to understand the signs and symptoms of newborns [...]. (N9)

In the speech above, the deponent living in the neonatal universe stands out, in an attitude of denaturalizing, of being stripped of science and coming to the natural to understand this universe and, in the future, to describe it with their experience. Thus, the nurse who worked with adult patients and who, for some reason, began to work in the care of the newborn at risk, in a phenomenological reduction, began to see and perceive the world in a different way.

Within this perspective, the nurses who started to inhabit the neonatal universe, both in the objective and in the subjective field, deconstructed and built experiences as other professionals already inserted in this professional world. However, the previous speech of the deponent shows that he/she did not choose neonatology, and their stay in the neonatal world is generated by satisfactions, expectations and strengthening of scientific knowledge.

[...] you've 15, 20 years of practice and you still lower your voice to talk to the child and go there and speak to them with sweetness, so, to see that makes me very emotional, you know? [...]. (N22)

The professionals refer to the past with all their professional experience, making adaptations in their knowledge through the scientific improvement to a children's clientele, which is their current experience.

\section{Category 3 - Time spent by the nurse practitioner with the high-risk newborn}

With the immersion of the third category, "time spent by the nurse practitioner with the high-risk newborn", the nurse has a different look at the care given to high-risk newborns through their relationship with their involvement in a single stroke of the future in the present. Time (past, present, and future) is the subject's own means of existence as an active being, who forms intentions, and carries with themselves, in the present, a sense of what has passed, as well as the sensation of the future over the present, that is, the past, the present and the future do not have the same sense of being ${ }^{(7)}$.

[...] sometimes we are not in a good moment, overworked, in the day-to-day rush, inside the ICU, and many things go unnoticed, and we have to stop, give it some time, to be able to understand everything that the child is trying to show us. (N08) 
By having a differentiated look at the care given to the high-risk newborn, believing in a world happens through the relationship and involvement with the infant, through the perception in the sense of being involved, in a single blow, to the whole future of a present that is never guaranteed. This is what makes this perception of a being in the world and that allows the opening of experiencing the present, linking the past to the present with perspectives in the future.

[...] / was very agonized to work with them at a first moment, with newborns, and because you knew that the baby was very much expected, not by all mothers, but by the vast majority [...], there, at the time they are born, not being what their mother expected, so that made me scared, fearing [...]. (N16)

The speech above says that the baby idealized by the mother and that is currently inside an ICU, causes feelings of fear, anguish and apprehension by the nurse practitioner. By knowing how to understand the newborn and their family in such painful moments, the nurse learns to minimize so much suffering, starting with their own, in an attitude of intersubjectivity.

\section{DISCUSSION}

In the book Phenomenology of Perception, Merleau-Ponty ${ }^{(7)}$ points out that the human body resembles a work of art, since it does not seem more than a thing among the others, it is also the thirst in which all meanings are articulated. This body, discreetly illuminated by subjectivity, shows itself as a fabric of things and spirit, and of non-meaning, as the meeting of living experiences ${ }^{(7)}$.

For this philosopher, the objective and physiological body is what can be observed, studied, researched, divided into parts such as tissues and organs with specific functions. The experienced body is the driver of the being, and is in the world just as our organs are in our organism, maintaining the spectacle, giving visibility to life, feeding it inwardly and forming a system. The being, when communicating through the body, has a passage to the world, as it reaches those who represent the reason for all the experiences that can be lived through a perceptive process ${ }^{(7)}$.

In addition, the findings of a study emphasize that professionals know the importance of humanizing care, because it is a process that guarantees the improvement of their quality and, consequently, the quality of life of newborns. However, they do not work in this perspective when they characterize their care practices $^{(11)}$. In this sense, aware of a warm and humane care to the newborn, they do not recognize putting them into practice.

It was also possible to observe that the professionals can understand some particularities of the preterm neonate, which makes a difference in the care provided, such as apnea, differentiated feeding, the fragility of the skin, bones and body systems such as immune, respiratory, gastrointestinal and nervous ${ }^{(12)}$.

Faced with this placement, studies emphasize that one of the care provided in the neonatal intensive care unit is prone positioning, that is, ventral decubitus of the newborn, favoring the reduction of stress instead of keeping them in traditional positions ${ }^{(13)}$.

In this sense, the results point to Merleau-Ponty's look, who is concerned with the human being as a subject body, since concrete life is always incarnated and there is no thought that does not count on sensitive experience. In spite of this, he recognizes the body (the experienced body) as the essence of the subject by which it is constructed, becomes an individual world and is inserted in the given world, in a situation of circumstantial time and space that contributes to the constitution of subjectivity and expressiveness of the subject ${ }^{(7)}$.

Therefore, the nurse can help these parents by paying attention to such signs and offering coping strategies, and, before anything, it is necessary to understand the feelings they may face. Parents should also receive an individualized family and empathetic care education ${ }^{(14)}$.

In this sense, when a newborn is facing complications, common in prematurity, there are doubts about the fact that life must be preserved at all costs. This is especially true in American society, where there is a belief in a form of vitalism: the idea that a long and healthy life, especially desirable, is a right of every individual, morally qualified to live as much as possible and to be as healthy as possible. Because of this, newborns receive high-quality care and, in many cases, have their lives saved. Even if compared to only a decade ago, fewer newborns are dying ${ }^{(15)}$.

The nurses' reports elect the neonatal environment of equipment acquisition, staff acquisition and, despite all the machinery that composes the neonatal unit, all the experience of the nurse practitioner that surrounds this objective world, the prioritization of humanized contact with the family, and keen observation to the phenomenal body have to prevail.

However, with the acquisition of the use of technology in neonatology, the proposal of a study emphasizes as a fundamental tool for nursing care the optimization of time directed to the newborn, maximizing the quality of the NICU integral care and facilitating communication between the multiprofessional team ${ }^{(11)}$.

Communication between the multiprofessional team and the nurse, through the immediate care of newborns, develops actions about this process, being able to intervene, if necessary, faced with the real needs of the child, implementing new ways of caring ${ }^{(16)}$.

Another point worth mentioning, based on new forms of care, is the applicability of information and communication technologies, expanding access to scientific knowledge through online education and contributing to the training of experienced and newly graduated professionals, improving knowledge in their areas of practice ${ }^{(17)}$.

The child and their family should also be observed within a phenomenological view: the Merleaupontian look for childhood would call for greater sensitivity to children at school, in the theater, in buffets and in public spaces, on beaches, swimming pools, changing rooms, means of transport and in hospitals ${ }^{(18)}$.

A study indicates that hospital admission is considered an event in which the mother of the newborn hospitalized in an NICU faces and witnesses painful care performed to the newborn, and, in the future, she will be able to participate effectively in this care and to feel as a mother ${ }^{(19)}$. Merleau-Ponty once again gives a new meaning to "objective" and "subjective". For someone who believes in objective assumptions, that time is only subjective, unreal, imaginary, and a human invention, he disagrees. The time of the past, present and future is subjective because it can only exist if there are subjects capable of experiencing them in this way ${ }^{(20)}$.

A study from South Korea demonstrates that it is of utmost importance to note that the separation from their mother and 
the NICU environment are limited to the interaction of the visual, auditory and tactile senses between mother and child, causing anxiety in the mother, which affects the maternal bond. Moreover, it is a stressful experience for them, since they feel guilty for thinking that the delivery was premature due to carelessness ${ }^{(21)}$.

Therefore, in an attitude of intersubjectivity, that is, involvement with the family, the nurse, in addition to performing care directed to the mother and child binomial, mediating this bond, also brings together other family members such as parents, grandparents and children, sharing this delicate moment.

\section{Limitations of the study}

The limiting factor of this research was the scarcity of publications concerning the care of newborns in the neonatal universe, having the theoretical, philosophical and methodological framework of the philosopher Maurice Merleau-Ponty. It is pertinent to highlight that, because the study was contextualized in only one NICU, for comparison purposes, new studies should be developed contemplating other neonatal units in the city of Rio de Janeiro, so that other professionals who are new to neonatology and those already in practice benefit from a comprehensive and effective care.

\section{Contributions to the field of nursing, public policy}

It is hoped that the research contributes to the qualification and improvement in education and health of nursing professionals who need to renew the care provided to high-risk newborns, considering the dimension of the being in order to contemplate a holistic and quality care in order to provide subsidies for nurses to develop their care activities.

Thus, the contribution of the study may stimulate health professionals, that is, a multiprofessional team, on the need for reflections on public health policies linked to neonatal care and to the family in order to ensure the health and constitutional rights pertinent to them.

\section{FINAL CONSIDERATIONS}

The study allowed us to describe, through the participants' speeches, that the care of the high-risk newborn is broad, that is, objective, subjective and carried out with advanced technologies, their experiences and scientific improvement are composed of practice and theory shared with the family, professionals and beginners in the neonatal universe, favoring a differentiated and humanized care. However, some challenges faced by the nurse professional, such as a double work days and physical and emotional exhaustion, direct them to a certain decision making and reflection.

\section{FUNDING}

We'd like to thank FAPERJ (Foundation for Research Support of the State of Rio de Janeiro) the financial support for the final preparation of the article.

\section{REFERENCES}

1. Barbosa VM. Teamwork in the Neonatal Intensive Care United. Phys Occup Ther Pediatr. 2013;33(1):5-26. doi: 10.3109/01942638.2012.729556

2. Savieto RM, Leão ER. Assistência em Enfermagem e Jean Watson: uma reflexão sobre a empatia. Esc Anna Nery. 2016;20(1):198-202. doi: 10.5935/1414-8145.20160026

3. Oliveira EB, Silva AV, Perez Jr EF, Costa HF, Nascimento LP. Psychosocial risk factors in neonatal intensive care unit: impact to the nurse's health. Rev Enferm UERJ [Internet]. 2013 [cited 2018 Mar 09];21(4):490-5. Available from: https://www.e-publicacoes.uerj.br/index.php/ enfermagemuerj/article/view/10020/23529

4. Medeiros FVA, Alves VH, Valete COS, Paiva ED, Rodrigues DP. The correlation between invasive care procedures and the occurrence of neonatal sepsis. Acta Paul Enferm. 2016;29(5):573-8. doi: 10.1590/1982-0194201600079

5. Dolack M, Huffines B, Stikes R, Hayes P, Logsdon M. Updated Neonatal Skin Risk Assessment Scale (NSRAS). Ky Nurse. $2013 ; 61$ (4):6.

6. Dias MS, Ribeiro SNS, Walt CMRF, Cabral LA. Atuação do enfermeiro no cuidado ao recém-nascido: proposta de um novo modelo. $R$ Enferm Cent O Min. 2016;1(6):1930-44. doi: 10.19175/recom.v0i0.919

7. Merleau-Ponty, M. Fenomenologia da percepção. São Paulo: Martins Fontes; 2015.

8. Cappi A. Apresentação. In: Petrelli R, organizador. Fenomenologia: teoria, método e prática. Goiânia: Editora UCG; 2004 . p. 7-8.

9. Andrade CC, Holanda AF. Apontamentos sobre a pesquisa qualitativa e pesquisa empírico-fenomenológica. Estud Psicol. 2010;27(2):259-68. doi: 10.1590/S0103-166X2010000200013

10. Costa MAF, Costa MFB. Metodologia da pesquisa: conceitos e técnicas. Rio de Janeiro: Interciência; 2001.

11. Lima JJ, Vieira LGD, Nunes MM. Computerized nursing process: development of a mobile technology for use with neonates. Rev Bras Enferm. 2018;71(Suppl 3):1273-80. [Thematic Issue: Health of woman and child] doi: 10.1590/0034-7167-2017-0267

12. Silva LG, Araújo RT, Teixeira MA. O cuidado de enfermagem ao neonato pré-termo em unidade neonatal: perspectiva de profissionais de enfermagem. Rev Eletr Enf. 2012;14(3):634-44. doi: 10.5216/ree.v14i3.12531

13. Toso BRGO, Viera CS, Valter JM, Delatore S, Barreto GMS. Validation of newborn positioning protocol in Intensive Care Unit. Rev Bras Enferm. 2015;68(6):835-41. doi: 10.1590/0034-7167.2015680621i 
14. Vitale S, Falco C. Children born prematurely: risk of parental chronic sorrow. J Pediatr Nurs. 2014;29(3):248-51. doi: 10.1016/j. pedn.2013.10.012

15. Costa R, Locks MOH, Klock P. Acolhimento na unidade neonatal: percepção da equipe de enfermagem. Rev Enferm UERJ [Internet]. 2012 [cited 2017 Oct 21];20(3):349-53. Available from: http://www.e-publicacoes.uerj.br/index.php/enfermagemuerj/article/view/2382

16. Refrande SM, Silva RMCRA, Pereira ER. Descriptive study of hospitalized child care: a Merleau-Ponty phenomenological approach. Online Braz J Nurs. 2012;11(2):524-7. doi: 10.5935/1676-4285.2012S025

17. Bussotti EA, Leite MTM, Alves ACC, Cristensen K. Online training for health professionals in three regions of Brazil. Rev Bras Enferm. 2016;69(5):924-8. doi: 10.1590/0034-7167.2016690506

18. Machado MM. Merleau-Ponty \& a Educação. Belo Horizonte: Autêntica; 2010.

19. Frello AT, Carraro TE. Enfermagem e a relação com as mães de neonatos em Unidade de Terapia Intensiva Neonatal. Rev Bras Enferm. 2012;65(3):514-21. doi: 10.1590/S0034-71672012000300018

20. Mathews E. Compreender Merleau-Ponty. Rio de Janeiro: Vozes; 2010.

21. Cho ES, Kim SJ, Kwon MS, Cho H, Kim EH, Jun EM, et al. The effects of Kangaroo Care in the Neonatal Intensive Care Unit on the physiological functions of preterm infants, maternal-infant attachment, and maternal stress. J Pediatr Nurs. 2016;31 (4):430-8. doi: 10.1016/j. pedn.2016.02.007 